\title{
Impact of Inflation and Exchange Rate on Stock Market Behaviour: Evidence from India
}

\section{*Dr. Anindita Chakraborty}
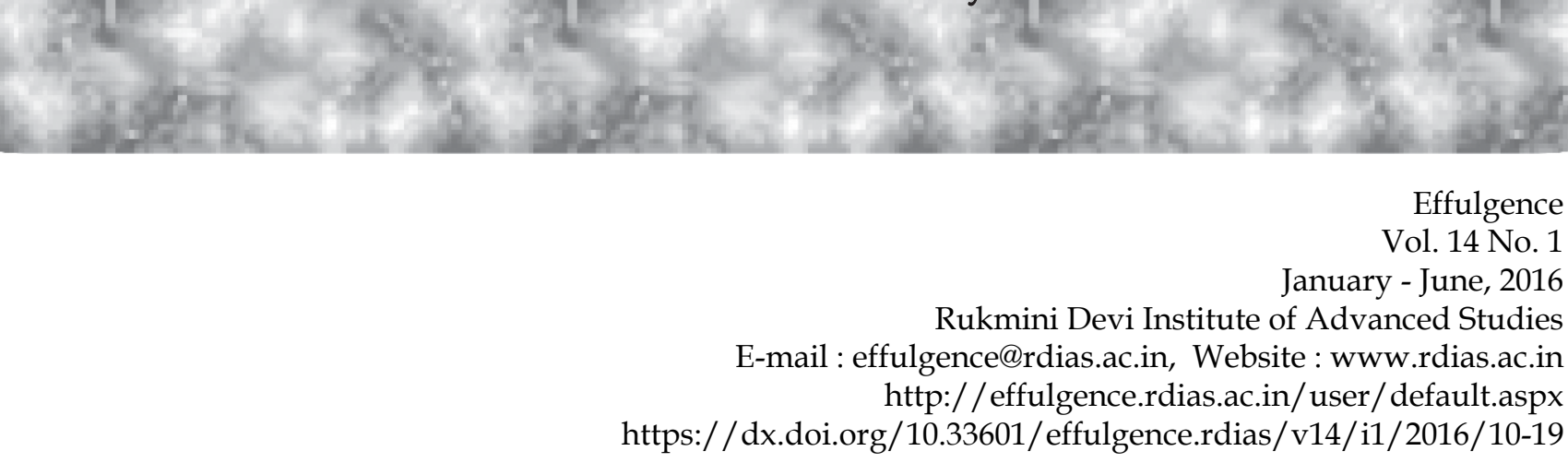

\begin{abstract}
The study investigates the effect of inflation rate and exchange rate on the performance of the Indian stock market using yearly data over the period from January 1991 to December 2014. By applying Augmented Dickey Fuller (ADF) unit root test, Granger Causality test, Johansen Cointegration test, and Vector Error Correction Model (VECM), the study found that inflation rate, exchange rate and market return were I (1). It mans that they are stationary at first difference. The study also revealed that there was causality run from exchange rate to stock market return but there was no long run relationship between inflation, exchange rate and stock market return. This shows that investors must critically evaluate the investment scenario before investing because inflation and exchange rate risk are part of systematic risk which cannot be controlled by them. Therefore, for better results investors must follow some active strategy.
\end{abstract}

Key Words: Inflation rate, Exchange rate, Unit Root test, Granger Causality test, Cointegration test and Vector Error Correction Model.

\section{INTRODUCTION}

$S$ tock market, particularly in developing economies, plays a crucial role in mobilizing financial resources within and outside the economy to achieve their better economic potentials (Aliyu, 2011). Investors are entering into the world's newest markets and some are seeing attractive returns (Levine 1996). These markets are serving as an important channel through which funds flow from one economy to other economy through various intermediaries. Previous researches have shown the role of financial development to the economic growth of countries. In general, there exists vast literature that has already proven the fact that well functioning financial intermediaries have played a vital role in economic growth of a country (King and Levine, 1993; Levine and Zervos, 1998; Seetanah, 2008).

But developing stock markets face numerous domestic and international factors directly or indirectly which affect their performance. A higher stock return entails higher profitability by firms and as a result overall growth of an economy and vice versa. Stock market volatility brings uncertainty in the mind of investors, which has a harmful effective on performance of the financial sector as well as on the whole economy. If there is an unexpected increase in volatility today then it leads to the upward revision of future expected volatility and risk premium which further leads to discounting of future expected cash flows (assuming cash flows remains the same) at an increased rate which results in lower stock prices or negative returns today (Pindyk, 1984).

Factors like inflation and exchange rate have a direct effect on the stock market performance. Inflation means the rise in price of goods and services which in turn reduces the purchasing power each unit of currency can buy. Rising inflation has an insidious effect: input prices are higher, consumers can purchase fewer goods, revenues and profits decline, and the economy slows for a time until a steady state is reached. Once the unanticipated inflation works its way through the levels 
of economy, the impact of a higher steady state of inflation can have varying effects. For investors, this can cause confusion, since inflation appears to impact the economy and stock prices, but not at the same rate. Numerous studies have looked at the impact of inflation on stock returns. Unfortunately, these studies have produced conflicting results when several factors are taken into account - namely geography and time period (Schwert, 1989; Davis and Kutan, 2003; Hamilton and Lin, 1996, Engle, 2004, Rizwan and Khan, 2007). Most studies have showed a strong positive correlation between inflation to stock returns during economic contractions, representing that the timing of the economic cycle is predominantly important for investors to measure the impact. This correlation gives the notion that unexpected inflation contains new information about future prices. Similarly, greater volatility of stock movements was correlated with higher inflation rates.

Similarly, the issue of inter-temporal relationship between exchange rates and stock market is becoming important these days with growing financial liberalization and globalization of stock markets. According to Joseph (2002) exchange rate changes directly influence the international competitiveness of firms, given their impact on input and output price. Investors today not only invest in their respective market but also try to explore the new developing markets to earn good returns. The continuing increases in the world trade and capital movements made the exchange rates as one of the main determinants of business profitability and equity prices (Kim, 2003). For this reason the relationship between exchange rates and stock returns has recently researched by economists, for both theoretical and empirical purpose, because they play an important role in affecting the development of a country's economy. In addition, this relationship is also exploited by investors in forecasting the future trends. Basically, foreign exchange rate volatility influences the value of the firm since the future cash flows of the firm change with the fluctuations in the foreign exchange rates (Agrawal et al., 2010).

The aim of this paper is to investigate the effects of inflation and exchange rate on the stock market behaviour with reference to India. The remainder of the paper is organized in the following sections: Section 2 provides Review of Literature. Section 3 discusses Data and Methodology. Empirical Analysis is presented in Section 4. The study is concluded in Section 5.

\section{REVIEW OF LITERATURE}

\section{A) Relationship between Inflation and Stock Market}

In one of the earlier studies Mayya (1977) studied the movement of share prices with a view to assessing the extent to which investment in stocks can act as a hedge against inflation. He found that in some years of inflation, the equity prices decreased and in some years of inflation, they increased and thus he concluded that shares are not a reliable hedge against inflation. Kaul (1986) found that the relationship between inflation and stock returns are dependent on the equilibrium process in the monetary sector and that they vary if the underlying money demand and supply factors undergo a systematic change. Schwert (1989) studied the relationship between stock market volatility and volatility of real and nominal macroeconomic variables and concluded that movements in inflation and real output have weak predictive power on volatility of stock market return. Rao and Bhole (1990) examined the relation between return on equity and inflation in India and found that over longer periods of time, positive real rate of return was being provided by equities, but in the short-run, the real return was often negative especially in years of high and extraordinary inflation. Contradictory to this, Boudoukh and Richardson (1993) established a strong support for positive relation between nominal stock return and inflation in long horizon.

Adrangi, Chatrath, and Sanvicente (2000) investigated the relationship between stock returns and inflation rates in Brazil. They concluded that there was negative relationship between inflation and real stock returns. The results also support an interesting notion that there was proxy effect in the long-run rather than short run. Geyser and Lowies (2001) concluded that South African companies listed in the mining sector are negatively correlated against inflation. The selected companies in financial services, information technology, and food and beverage sectors showed a little positive correlation 
between stock price changes and inflation. In addition, Engle and Rangel (2005) concluded that countries with high rates of inflation experience larger expected volatilities than those with more stable prices.

Positive relationships between inflation and stock returns were also revealed by Luintel and Paudyal (2006). They argued that the nominal return from stock investments must exceed the inflation rate in order to fully protect tax-paying investors. Otherwise, investors will suffer real wealth losses. Similarly, Boucher (2006) measured a new angle on the relationship between stock prices and inflation, by estimated the common long-term trend in the earning-price ratio and inflation. He examined the role of the transitory deviations from this common trend for forecasting stock returns and concluded that these deviations exhibit substantial out-ofsample forecasting abilities for excess stock returns at short and intermediate horizons. Similarly, Saryal (2007) evidenced a strong time varying volatility in Turkey and Canadian stock markets and found that the rate of inflation was one of the underlying determinants of conditional market volatility in Turkey, which had higher inflation rate than Canada.

Yaya and Shittu (2010) in their study revealed that the previous inflation rates have significant effects on conditional stock market volatility. Geetha et al. (2011) investigated the relationship between stock market, expected inflation rate, unexpected inflation rate, exchange rate, interest rate and GDP in the case of Malaysia, US and China. The results of the study depicted a significant short-run relationship in between stock market and expected inflation rate of China. Secondly, there was also a significant relationship between exchange rate and stock market in China. Therefore, investors may not gain any portfolio diversification benefits in the shortrun. Similarly, Aliyu (2011) concluded that inflation rate and its three month average were found to have significant effect on stock market volatility in the Nigeria and Ghana.
B) Relationship between Exchange Rate and Stock Market

The relationship between exchange rate and stock prices has received considerable attention in research during 1980's and 1990's, when the countries started adopting more flexible exchange rate regimes which has increased the volatility of foreign exchange markets and the risk related with such investments. The preference for currency denomination has added an important facet to the overall portfolio choice. Classical economists suggest relationship between the stock market performance and the exchange rate behaviour. It state that currency movements affect international competitiveness and the balance of trade position, and consequently the real output of the country, which in turn affects current and future cash flows of companies and their stock prices (Dornbusch and Fisher, 1980). Similarly, movements in the stock market may also affect exchange rates.

Early studies in this area considered only the correlation between the two variables-exchange rates and stock returns. Aggarwal (1981) and Roll (1992) revealed a positive relationship between exchange rate and stock market returns. Soenen and Hennigar (1988) contrasted this opinion by finding a significantly negative relationship between both of them. On the other hand Chow et al. (1997) found contradictory results. They used monthly data for the period 1977-1989 and showed no relationship for monthly excess stock returns and real exchange rate returns. But when they repeated the exercise with longer than six months period; they found a positive and strong relationship between a dollar and stock returns.

Phylaktis and Ravazzolo (2005) examined whether the linkage between exchange rate and stock prices were affected by the existence of foreign exchange controls, and by the Asian financial crisis of mid 1997 and they suggested that there exists a long-run and short-run dynamics between stock prices and exchange rates in a group of Pacific Basin countries. Ali et al. (2010) disclosed that exchange rate has no co-integration with stock exchange price index in Pakistan. They further reported that there was no 
granger causality between exchange rate and stock market performance.

Olugbenga (2012) reported a significant positive stock market performance to exchange rate in the short-run and a significant negative stock market performance to exchange rate in the long-run. Results of the study also showed that causation runs from exchange rate to stock market performance. Subair and Salihu (2013) investigated the effects of exchange rate volatility on the Nigerian stock market and reported that the exchange rate volatility generated via GARCH process exerts a stronger negative impact on the Nigerian stock market. They recommended that a coordinated monetary and fiscal policy should be put in place to check the fluctuation of exchange rate in order to deepen the stock market.

Lawal and Ijirshar (2015) conducted the study on relationship between key macroeconomic indicators specifically exchange rate and inflation rate and their impact on Nigerian stock market. The results showed negative impact on the growth of Nigerian stock market through GARCH process and ECM estimation techniques while interest rate was found to have positive impact. It was further stated that long run volatility in exchange rate has strong negative impact on the change in the performance of the Nigerian stock market having proved the unidirectional relationship through pair-wise granger causality test.

\section{DATA AND METHODOLOGY}

The study used yearly data for the period 1991 to 2014 . The data for inflation were obtained from official website of UNCTAD. The Bombay Stock Exchange (BSE) sensex was taken as a proxy for stock market and the historical data were obtained from the official website of BSE on yearly basis from 1991 to 2014. The exchange rate data used in the model were the yearly average rate obtained from Ozforex.com. To test the effect of inflation and exchange rate on market performance, the following model have been used denoted as shown below where the variables have been transformed by taking the natural logarithms;

Stock Market Return $=\mathrm{f}$ (Inflation, Exchange rate)
For calculation purpose the natural logarithms for BSE Sensex (Mkt_Return) yearly closing prices, consumer price index (Lninfl) and exchange rate (Lninr_usd) were taken.

\section{Tools Used}

To study the long-term relationship among inflation, exchange rate and stock market return a common practice in the literature is to apply Johansen's cointegration method and the maximum Eigen value test. The short-term relationship between is explored by using the Granger causality tests or the Error Correction Model (ECM) approach.

\section{i. Unit Root Test}

Following the traditional three step procedure of Engle and Granger to test the direction of causality, and cointegration, the first step was to check for the order of integration through unit root tests and if the unit root is present, then stationarity is achieved by the first differencing of the data. There are several available tests for testing for a unit root, in this study to examine and make the series stationary of oil prices and stock market prices the Augmented Dickey-Fuller (ADF) unit root test was applied. The complete model of ADF Unit Root Test can be written like this:

$\Delta \mathrm{y}_{\mathrm{t}} \alpha+\beta \mathrm{t}+\gamma \mathrm{y}_{\mathrm{t}-1}+\delta_{1} \Delta \mathrm{y}_{\mathrm{t}-1}+\ldots \ldots \ldots \ldots+\delta_{\mathrm{p}} \Delta \mathrm{y}_{\mathrm{t}-\mathrm{pt}} \varepsilon_{\mathrm{t}}$,

The ADF regression tests for the existence of unit root of $y_{t}$ namely in the logarithm of all model variables at time t. The variable $\Delta \mathbf{y}_{\mathrm{t}}$ expresses the first differences and $\varepsilon_{\mathrm{t}}$ is the variable that adjusts the errors of autocorrelation. Where is a constant, the coefficient on a time trend and $\mathrm{p}$ the lag order of the autoregressive process. Imposing the constraints

$=0$ and $=0$ corresponds to modeling a random walk and using the constraint $=0$ corresponds to modeling a random walk with a drift.

\section{ii. Granger Causality Testing}

A variable $\mathrm{x}$ is said to Granger cause another variable $\mathrm{y}$ if past values of $\mathrm{x}$ help predict the current level of $y$ given all other appropriate information. 


\section{iii. Johansen's Cointegration Test}

The next step is to applying the VAR approach of Johansen-Juselius (1990), where we test for cointegration. The finding that many macro time series may contain a unit root has spurred the development of the theory of non-stationary time series analysis. The purpose of the cointegration test is to determine whether a group of non-stationary series is cointegrated or not. The existence of a cointegrating relationship means that a long-run equilibrium relationship exists among the cointegrating variables. Cointegration pre-supposes causality in at least one direction, and this may be determined by employing a vector error correction model (VECM). Beginning with a simple VAR model with $\mathrm{k}$ lags such as in equation below:

Consider a VAR of order $\mathrm{p}$ :

$$
\mathrm{y}_{\mathrm{t}=} \mathrm{A}_{1} \cdot \mathrm{y}_{\mathrm{t}-1}+. .+\mathrm{A}_{\mathrm{p}} \cdot \mathrm{y}_{\mathrm{t} p}+\cdot \mathrm{x}_{\mathrm{t}+\mathrm{t}}
$$

where, $y_{t}$ is a k-vector of non-stationary, I(1) variables, i.e. when we see two time series $\mathrm{x}$ and $\mathrm{y}$ they get stationary at first difference I(1) or we can say integrated at order one series, $\mathrm{x}_{\mathrm{t}}$ is a vector of deterministic variables, and ${ }_{t}$ is a vector of innovations. We can rewrite the VAR as:

$\Delta y_{t}=\Pi y_{t-1}+\sum_{i=1}^{p-1} \Gamma_{i} \cdot \Delta y_{t-i}+\beta \cdot x_{t}+\varepsilon_{t}$
where $\Pi=\sum_{i=1}^{p} A_{i}-I, \quad \Gamma_{i}=-\sum_{j=i+1}^{p} A_{j}$

Granger's representation theorem (i.e. Error correction Model) asserts that if the coefficient matrix has reduced rank $r<k$, then there exist $k^{*} \mathrm{r}$ matrices and each with rank $r$ such that $=$ ' and ' $y$ is stationary $\mathrm{I}(0) . \quad R$ is the number of cointegrating relations (the cointegrating rank) and each column of is the cointegrating vector. The elements of are known as the adjustment parameters in the vector error correction model. Johansen's method is to estimate the matrix in an unrestricted form, then test whether we can reject the restrictions implied by the reduced rank of .

\section{iv. Vector Error Correction Model (VECM)}

Finally when the result of the study confirmed that the variables were cointegrated the Vector Error Correction Model was conducted to determine the number of cointegrating equations. The principle behind these models is that there often exists a longrun equilibrium relationship between two economic variables. In the short run, however, there may be disequilibrium. With the error correction mechanism, a proportion of the disequilibrium in one period is corrected in the next period. The error correction process is thus a means to reconcile shortrun and long-run behavior. It relates the change in $y$ to the change in $\mathrm{x}$ and the past period's disequilibria. The Model of VEC can be written as:

$$
\begin{aligned}
& \Delta y_{1, t}=r_{1} \cdot\left(y_{2, t-1}-\beta \cdot y_{1, t-1}\right)+\varepsilon_{1, t} \\
& \Delta y_{2, t}=r_{2} \cdot\left(y_{2, t-1}-\beta \cdot y_{1, t-1}\right)+\varepsilon_{2, t}
\end{aligned}
$$

The only right-hand side variable is the error correction term, $\left(\mathrm{y}_{2, t-1^{-}} \cdot \mathrm{y}_{1, \mathrm{t}-1}\right)$. If $\mathrm{y} 1$ and $\mathrm{y} 2$ deviated from long run equilibrium last period, then ( $\mathrm{y} 2, \mathrm{t}-1$ . $y 1, t-1) \neq 0$ and each variable adjusts to partially restore the equilibrium relation. The coefficients $\mathrm{r} 1$ and $\mathrm{r} 2$ measure the speed of adjustment.

\section{EMPIRICAL RESULTS}

\section{A) Descriptive Statistics and Test for Normality}

The study has employed the Jarque-Bera test to test for the normality in the time series data variables. The following is the hypothesis for Jarque-Bera test:

\section{$\mathrm{H}_{0}: \mathrm{JB}=0$ (normally distributed) $\mathrm{H}_{1}: \mathrm{JB} \neq 0$ (not normally distributed)}

Table 1 revealed that the Jarque-Bera statistic after logarithmic transformation of the variables was not significantly different from zero, thereby implying that all the variables were normally distributed at 5\% significance level. It was also clear that the calculated pvalue was greater than any usual significance level (such as $=0.10,0.05$ or 0.01 ) which suggests that there was no evidence to reject the null hypothesis of a normal distribution for all the variables. The other descriptive statistics for the variables were summarized in the table. 
Table 1: Descriptive statistics and Test for Normality

\begin{tabular}{|l|c|c|c|}
\hline Statistics & MKT_Return & Lninfl & Lninr_USD \\
\hline Mean & 13.61252 & 7.545567 & -5.205992 \\
Median & 16.56241 & 7.469114 & -4.396660 \\
Maximum & 59.93407 & 12.98894 & 40.16561 \\
Minimum & -74.33007 & 3.698010 & -49.21548 \\
Std. Dev. & 32.48676 & 3.010627 & 15.69800 \\
Skewness & -0.732148 & 0.185350 & 0.045697 \\
Kurtosis & 3.400144 & 1.749222 & 6.265931 \\
Jarque-Bera & 2.304275 & 1.701864 & 10.67466 \\
Probability & 0.315961 & 0.427017 & 0.004809 \\
Sum & 326.7005 & 181.0936 & -124.9438 \\
Sum Sq. Dev. & 24273.96 & 208.4692 & 5667.828 \\
Observations & 24 & 24 & 24 \\
\hline
\end{tabular}

\section{B) Unit Root test}

Augmented Dickey-Fuller test was employed to test the stationarity of all the variables and the results were presented in table 2. The ADF approach controls for higher-order correlation by adding lagged difference terms of the dependent variable to the right-hand side of the regression. The results disclose that all the variables were found to be stationary at the first order level, and they were also integrated in the order of I (1), respectively.

Table 2: Augmented Dickey-Fuller Test Results

\begin{tabular}{|l|l|l|}
\hline Variables & Intercept & \multicolumn{1}{|c|}{ Intercept \& trend } \\
\hline I. Levels & \multicolumn{2}{|l|}{} \\
\hline MKT_RETURN & $-6.097004 *$ & $-5.910075^{*}$ \\
LNINFL & -2.929508 & -2.815763 \\
LNINR_USD & $-4.562851 *$ & $-4.462261 *$ \\
\hline II. First Difference & \\
\hline MKT_RETURN & $-6.482389 *$ & $-6.430949 *$ \\
LNINFL & $-6.136071 *$ & $-6.079710 *$ \\
LNINR_USD & $-6.518734 *$ & $-6.476936 *$ \\
\hline
\end{tabular}

(*) indicates significance at 5\%. Optimal lag length is determined by the Schwarz Information Criterion (SIC).

As the results revealed that all the variables were integrated at the same order, I(1), so co-integration techniques may be used to determine the existence of a stable long-run relationship between the variables. But first it was needed to test the short-run relationship between the variables and for that pair-wise Granger Causality tests was applied. 
Table 3: Pair-wise Granger Causality Tests

\begin{tabular}{|l|l|l|l|}
\hline CAUSALITY & MKT_RETURN & LNINFL & LNINR_USD \\
\hline MKT_RETURN & - & $0.35487(0.7063)$ & $0.35056(0.7093)$ \\
LNINFL & $0.38747(0.6846)$ & - & $1.27119(0.3059)$ \\
LNINR_USD & $5.51933(0.0142)^{*}$ & $0.00762(0.9924)$ & - \\
\hline
\end{tabular}

(* shows significant at $5 \%$ )

The table 3 showed the relationship between all the variables. The results demonstrated that there was unidirectional causality between exchange rate and stock market return $(p=0.0142<.05)$, which gave evidence that exchange rate fluctuations can affect the stock market performance in short-run. While there was no causality between inflation and market return as shown by the results.

D) Johansen's co-integration test

Table 4: Johansen's co-integration test

\begin{tabular}{|c|c|c|c|c|c|}
\hline Null Hypothesis $\left(\mathrm{H}_{0}\right)$ & $\begin{array}{l}\text { Alternate } \\
\text { Hypothesis }\left(\mathrm{H}_{2}\right)\end{array}$ & Eigen Value & $\begin{array}{l}\text { Likelihood } \\
\text { test ratio }\end{array}$ & $\begin{array}{l}0.05 \text { Critical } \\
\text { Value }\end{array}$ & P-value \\
\hline \multicolumn{6}{|c|}{ Trace Statistics } \\
\hline$r=0$ & $r \geq 1$ & 0.748294 & 46.08384 & 29.79707 & $0.0003 *$ \\
\hline $\mathrm{r} \leq 1$ & r 2 & 0.406550 & 15.73496 & 15.49471 & $0.0460 *$ \\
\hline R 2 & r 3 & 0.175867 & 4.255320 & 3.841466 & $0.0391^{*}$ \\
\hline \multicolumn{6}{|c|}{ Max-eigen statistic } \\
\hline$r=0$ & $r=1$ & 0.748294 & 30.34888 & 21.13162 & $0.0019^{*}$ \\
\hline$r=1$ & $r=2$ & 0.406550 & 11.47964 & 14.26460 & 0.1318 \\
\hline$r=2$ & $r=3$ & 0.175867 & 4.255320 & 3.841466 & $0.0391 *$ \\
\hline
\end{tabular}

Note: $r$ is the number of co-integrating vectors under the null hypothesis. $(*)$ denote the significance at $5 \%$.

Trace test and Maximum Eigen value (see table above) statistics signify the presence of three and one co-integrating vector respectively between all the variables at the five per cent level of significance. Here, we can check for the longterm relationship between inflation and exchange rate with stock market performance. The results showed that all the variables were co-integrated and there exists at most three co-integrating relationship. In other words, all the variables share common long-run information. 
Table 5: Results of VECM

\begin{tabular}{|l|c|c|c|}
\hline Error Correction & D(MKT_RETURN) & D(LNINFL) & D(LNINR_USD) \\
\hline CointEq1 & 0.009032 & 0.002454 & 0.172913 \\
& $(0.10384)$ & $(0.00884)$ & $(0.04773)$ \\
D(MKT_RETURN(-1)) & {$[0.08698]$} & {$[0.27751]$} & {$[3.62297]$} \\
& -0.570177 & 0.000593 & 0.067163 \\
& $(0.21484)$ & $(0.01830)$ & $(0.09875)$ \\
D(MKT_RETURN(-2)) & {$[-2.65394]^{* *}$} & {$[0.03240]$} & {$[0.68016]$} \\
& -0.264306 & -0.013833 & 0.108950 \\
D(LNINFL(-1)) & $(0.19127)$ & $0.01629)$ & $(0.08791)$ \\
& {$[-1.38188]$} & {$[-0.84913]$} & {$[1.23934]$} \\
D(LNINFL(-2)) & 3.449748 & -0.391492 & 2.318294 \\
& $(3.22706)$ & $0.27486)$ & $(1.48322)$ \\
& {$[1.06901]$} & {$[-1.42435]$} & {$[1.56302]$} \\
D(LNINR_USD(-1)) & 2.056848 & -0.226390 & 1.195295 \\
& $(3.07139)$ & $(0.26160)$ & $(1.41167)$ \\
& {$[0.66968]$} & {$[-0.86541]$} & {$[0.84672]$} \\
D(LNINR_USD(-2)) & -0.542147 & 0.027895 & 0.721137 \\
& $(0.84195)$ & $(0.07171)$ & $(0.38698)$ \\
& {$[-0.64392]$} & {$[0.38899]$} & {$[1.86352]$} \\
& 0.901786 & 0.016230 & 0.403081 \\
& $(0.70944)$ & $(0.06042)$ & $(0.32607)$ \\
& {$[1.27113]$} & {$[0.26860]$} & {$[1.23617]$} \\
\hline
\end{tabular}

("Significance level 5\%)

The table 5 shows several short-run and long-run causalities. Each column of the table represents the dependent variables. Each column shows the coefficients of each independent variable. The results revealed that the Indian stock market was not influenced by the inflation and exchange rate in long-run while in shortrun it was influenced by exchange rate as shown by Granger Causality test.

\section{CONCLUSION}

The paper attempted to investigate the impact of inflation and exchange rate changes on the performance of Indian stock market and for this purpose BSE Sensex was taken as a proxy. The results of the study depicted that there was no influence or causality from inflation to stock market return but there was unidirectional causality from exchange rate to stock market return. The results of this paper have important implications for investors and policy makers. The investors while investing in the stock market at present time generally need to consider a passive strategy, the findings suggest that when there are changes in inflation and exchange rates, investors should re-examine the composition of their portfolios due to the unexpected change in the riskreturn trade off. It is also important to mention here that inflation and exchange rate are two economic and financial risk factors which have a predictive power for stock market return and volatility in some sectors, therefore, investors ought to follow closely the monetary policies of the country to take appropriate investment decisions. 


\section{FUTURE AREAS OF RESEARCH}

Though the paper is limited to only two economic variables, the future researchers may include other variables also. Similarly the study is limited to India only, in future other emerging markets may be included to get a conclusive results and comparison between emerging and developed arkets must be done to find out the effect of these variables. This will help in finding out the vulnerable stock markets; helping investors as well as policy makers to take appropriate investment decisions.

\section{REFERENCES}

1) Adrangi, B. Chatrath, A. and Sanvicente, A. Z. (2000), "Inflation, Output and Stock Prices: Evidence from Brazil”, Working Paper, 34.

2) Aggarwal, R. (1981), "Exchange Rates and Stock Prices: A Study of the US Capital Markets under Floating Exchange Rates", Akron Business and Economic Review, (Fall): 7-12.

3) Agrawal, G., Srivastav, A. K., and Srivastava, A. (2010), "A Study of Exchange Rates Movement and Stock Market Volatility”, International Journal of Business and Management, 5(12):, 62-73.

4) Aliyu, S.U.R. (2011), "Does inflation has an impact on Stock Returns and Volatility? Evidence from Nigeria and Ghana", retrieved on 22 June, 2015 from http://www.csae.ox.ac.uk/conferences/2011edia/papers/054-aliyu.pdf

5) Boucher, C. (2006), "Stock-price inflation puzzle and the predictability of the stock Market returns", Economic Letters, 90: 205-212.

6) Boudoukh, J., and Richardson, M. (1993), "Stock Returns and Inflation: A Long-Horizon Perspective”, American Economic Review, 83: 13461355.

7) Chow, E.H., Lee, W.Y. and Solt, M.S. (1997), “The Exchange Rate Risk Exposure of Asset Returns", Journal of Business, 70: 105-123.

8) Davis, N. and Kutan, Ali, M. (2003), "Inflation and Output as Predictors of Stock Returns and Volatility: International Evidence”, Applied Financial Economics, 13: 693-700.

9) Dornbusch, R. and Fisher, S. (1980), "Exchange Rates and the Current Account", American Economic Review, 70: 960-971.

10) Engle, R. F. (2004), "Risk and Volatility:
Econometric Models and Financial Practice", American Economic Review, 94: 405-420.

11) Engle, R.F. and Rangel, J.G. (2005), "The SPLINE GARCH model for unconditional volatility and its global macroeconomic causes", Mimeo, Presented at the World Congress of the Econometric Society, London.

12) Geetha, C., Mohidin, R., Chandran, V. V. and Chong, V. (2011), "The Relationship between Inflation and Stock Market: Evidence from Malaysia, United States and China", International Journal of Economics and Management Sciences, 1(2): 1-16.

13) Geyser, J. M and Lowies, G. A. (2001), "The impact of inflation on stock prices in the SADC countrie", University of Pretoria, Working Paper, 14.

14) Hamilton, J.D and Lin, G. (1993), "Stock Market Volatility and the Business Cycle", Journal of Applied Econometrics, 11: 573-593.

15) Joseph, N. (2002), "Modelling the impacts of interest rate and exchange rate changes on UK Stock Returns”, Derivatives Use, Trading \& Regulation, 7(4): 306-323.

16) Kaul, G. (1987), "Stock returns and inflation: the role of monetary sector", Journal of Financial Economics, 18: 253-276.

17) Kim, K. (2003), "Dollar exchange rate and stock price: evidence from multivariate cointegration and error correction model", Review of Financial Economics, 12: 301-313.

18) King, Robert E. and Levine, R.(1993), "Financial intermediation and economic development" in Financial Intermediation in the Construction of Europe. Editors: Colin Mayer and Xavier Vives. London: Centre for Economic Policy and Research, pp. 156-89.

19) Lawal, M. and Ijirshar, V. U. (2015), "Empirical analysis of exchange rate volatility and Nigeria stock market performance", Retrieved on 24 June, 2015 from http://www.ijsr.net/archive/v4i4/10041502. pdf

20) Levine, R. and Zervos, A. (1998), "Stock markets, banks, and economic growth", American Economic Review, 88(3): 537-58.

21) Luintel, K.B., and Paudyal, K. (2006), "Are common stocks a hedge against inflation?”, Journal of Financial Research, XXIX (1): 119.

22) Mayya, M.R. (1977), "Do equities act as a hedge 
against inflation?”, Economic and Political Weekly, 12(22): 61-71.

23) Olugbenga, A. A. (2012), "Exchange rate volatility and stock market behaviour: The Nigerian experience", Research Journal of Finance and Accounting, 3(3): 88-93.

24) Phylaktis, K., and Ravazzolo, F. (2005), "Stock prices and exchange rate dynamics", Journal of International Money and Finance, 24(7): 1031-1053.

25) Pindyck, R. (1984), "Risk, inflation and the stock market”, American Economic Review, 74: 335-351.

26) Rao, Narayana and Bhole, L.M. (1990), "Inflation and equity returns", Economic and Political Weekly, 25(21): 91-96.

27) Rizwan, Mohammad Faisal and Khan, Safi Ullah (2007), "Stock return volatility in emerging equity market (KSE): the relative effects of country and global factors", International Review of Business Research Papers, 3(2): 362-375.

28) Roll, R. (1992), "Industrial structure and the comparative behaviour of international stock market indices", Journal of Finance, 47: 3-41.

29) Saryal, F. S. (2007), "Does inflation have an impact on conditional stock market volatility?: Evidence from Turkey and Canada”, International Research Journal of Finance and Economics, 11.

30) Schwert, G. William (1989), "Why does stock market volatility change over time?", Journal of Finance, 44, 1115-1153.

31) Seetanah, B. (2008), "Financial development and economic growth in an ARDL approach", Applied Economics Letter, 4(43): 43-50.

32) Soenen, L.A. and Hennigar, E.S. (1988), “An analysis of exchange rates and stock prices - the US experience between 1980 and 1986", Akron Business and Economic Review, (Winter): 7-16.

33) Subair, K and Salihu, O. M. (2013), "Exchange Rate Volatility and the Stock Market: The Nigerian Experience", Kwara State University, Malete, Nigeria.

34) Yaya, O. O. S. and Shittu, O. I. (2010), "On the impact of inflation and exchange rate on conditional stock market volatility: a re-assessment”, Retrieved on 22 June, 2015 from http://www.scihub.org /AJSIR/PDF/2010/2/AJSIR-1-2-115-117.pdf. 